Шабанов Виктор Леннарович

доктор социологических наук, ведущий научный сотрудник

Института аграрных проблем РАН

\section{ДЕПРИВАЦИОННЫЙ ПОДХОД В ИССЛЕДОВАНИЯХ БЕДНОСТИ}

\begin{abstract}
Аннотация:
В статье проведено сравнение абсолютного и депривационного подходов к пониманию бедности и ее исчислению. Показана недостаточная разработанность методики исчисления уровня депривационной бедности как в Росстате, так и Евростате. C использованием микроданных обследования бюджетов домашних хозяйств Росстата по итогам 2018 г. установлен различный, слабо пересекающийся состав групп монетарной и депривационной бедности, показана слабая зависимость уровня депривированности от уровня доходов. Установлено также, что часть факторов монетарной бедности (размер домохозяйства, количество детей в семье) не являются факторами депривационной бедности. Оценен масштаб распространенности депривационной бедности, в том числе в различных социально-демографических группах населения, а также при сравнении городской и сельской местности. Получены данные о наибольшем риске депривации населения, проживающего в домохозяйствах одиночек, инвалидов неработающих пенсионеров, и сделаны выводы о влиянии социально-психологического фактора на субъективное восприятие лишений.
\end{abstract}

Ключевые слова:

монетарная бедность, депривационная бедность, лишения, депривированность, факторы депривированности, домохозяйство, доход.

\section{Shabanov Viktor Lennarovich}

D.Phil. in Social Science, Leading Research Fellow, Agrarian Problems Institute, Russian Academy of Sciences

DEPRIVATION APPROACH IN STUDYING POVERTY

Summary:

The paper compares absolute and deprivation approaches to poverty understanding and its estimation. The insufficient development of the methodology for calculating the level of deprivation poverty in both Rosstat and Eurostat is shown. According to the results of 2018, using microdata from a Rosstat survey of household budgets, a different, slightly overlapping monetary and deprivation poverty group structure was established, and a weak dependence of the deprivation level on income was shown. It was also established that some of the monetary poverty factors (household size, number of children in a family) are not the factors of deprivation poverty. The prevalence of deprivation poverty was estimated, including in various socio-demographic population groups and also in comparing urban and rural areas. The data on the greatest risk of deprivation of the population living in households of single, disabled, unemployed retired people was collected, and conclusions about the influence of the socio-psychological factor on the subjective perception of deprivation were made.

Keywords: monetary poverty, deprivation poverty, deprivation, deprivation factors, household, income.

Бедность характеризуется отсутствием возможностей для людей вести минимально приемлемый образ жизни того сообщества, членами которого они являются [1]. Эти возможности могут определяться через доходы (и тогда речь идет об одной из монетарных концепций бедности - абсолютной или относительной), через субъективное восприятие или лишения (депривации) в различных сорерах. Исследования показывают ограниченность монетарных концепций анализа бедности, не дающих представления о самоощущениях индивида, находящегося в состоянии малообеспеченности, социальной уязвимости, депривации [2].

Целью настоящей статьи является анализ депривационной бедности - ее масштаба, охвата разных социально-демографических групп, ее связи с размером дохода.

Депривационный подход в исследованиях бедности известен с 1970-х гг., с работ П. Таунсенда [3]. Согласно ему, бедные выделяются на основе набора испытываемых ими лишений, приводящих к невозможности поддерживать соответствующий образ жизни. В Европе переход от чисто монетарного измерения бедности к измерению многомерной бедности, в составе которой оценивается не только уровень доходов, но также и уровни занятости и депривации, был осуществлен в 2010 г. [4]. В последние годы методика измерения бедности расширяется в России: с использованием европейского опыта также реализуется переход к концепции многомерной бедности, включающей анализ деприваций [5].

Депривационный подход в большей степени, чем монетарные подходы, ориентирован на объяснение социального поведения людей, поскольку испытываемые лишения определяются не одними только доходами. Так, домохозяйство, имеющее достаточно высокие доходы - выше прожиточного минимума или другого установленного порога, - может оказаться бедным по лишениям из-за специфики своих расходов, определяемой, например, завышенными долями лекарств, спиртного, каких-либо услуг [6]. Образ жизни индивидов, составляющих такое небедное 
по доходам домохозяйство, скорее всего, будет соответствовать усредненным представлениям о бедности, сложившимся в данном обществе в данное время.

Важнейшая задача при измерении депривационной бедности - определение списка лишений [7]. Подход, принятый в Евростате, относит к депривированным тех, кто по причине нехватки финансовых средств испытывает лишения как минимум в трех сферах из девяти включенных в список. В составе списка - лишения в сфере потребления, связанные с экономическими трудностями (невозможностью оплатить коммунальные услуги и аренду жилья, отопление, недельный отдых, покупку мяса и рыбы) и с трудностями приобретения товаров длительного пользования (автомобиля, стиральной машины, телевизора, телефона) [8]. С 2016 г. данный подход реализуется в двух обследованиях Росстата - «Выборочном наблюдении доходов населения и участия в социальных программах» и «Комплексном наблюдении условий жизни населения», являющихся в настоящее время основными источниками данных по измерению бедности [9]. Расчеты на материалах 2016 г. показывают довольно высокий уровень лишений: 41,3 \% респондентов отметили отсутствие возможности покупать каждому члену семьи две пары обуви, 64,1 \% - невозможность заменить старую мебель, 38,7 \% - невозможность провести неделю отпуска вне дома [10]. Полученные данные, по-видимому, отражают реальную ситуацию, однако прямое, неадаптированное применение к ним методики Евростата для измерения депривационной бедности привело бы к ее оценкам в $33,1 \%$, что сильно завышено по сравнению с уровнем абсолютной бедности $(13,5 \%)$. В то же время получить более реалистичную оценку уровня лишений можно, используя другие показатели, изначально не связанные непосредственно с измерением депривационной бедности. Один из таких показателей, присутствующих в бюджетном обследовании домохозяйств Росстата в неизменном виде по крайней мере с 2004 г., представляет собой список из пяти финансовых возможностей, усиливающихся по мере продвижения к концу списка - от нехватки денег на еду до возможности любой покупки. К числу бедных обычно относят респондентов, оказавшихся по самооценке возможностей в первых двух градациях - «доходов не хватает даже на еду» и «затруднительно покупать одежду и оплачивать жилищно-коммунальные услуги» [11]. Анализ показывает, что уровень депривационной бедности, определяемой таким образом, в течение 2004-2018 гг. в целом снизился с 41,4 \% до 16,3 \%; рост наблюдался в 2009, 2015 и 2016 гг. [12].

Связь депривационной бедности с показателем доходов, очевидно, обратная, однако она менее выраженная, чем в случае монетарной бедности (табл. 1).

Таблица 1 - Группировка населения России по оценке своих финансовых возможностей *

\begin{tabular}{|l|c|c|}
\hline \multicolumn{1}{|c|}{ Группа } & $\begin{array}{l}\text { Распределение } \\
\text { численности, \% }\end{array}$ & $\begin{array}{c}\text { Денежные доходы, } \\
\text { тыс. р. на чел. в месяц }\end{array}$ \\
\hline $\begin{array}{l}\text { 1-2. Бедные по депривации: доходов не хватает } \\
\text { даже на еду \& затруднительно покупать одежду } \\
\text { и оплачивать жилищно-коммунальные услуги }\end{array}$ & 16,3 & 14,6 \\
\hline $\begin{array}{l}\text { 3. Не могут позволить покупку товаров } \\
\text { длительного пользования }\end{array}$ & 49,3 & 20,0 \\
\hline 4. Не хватает денег на покупку автомобиля & 23,7 & 30,6 \\
\hline 5. Не хватает денег на покупку квартиры, дачи & 7,6 & 38,0 \\
\hline $\begin{array}{l}\text { 6. Средств достаточно, чтобы купить все, } \\
\text { что считают нужным }\end{array}$ & 3,1 & 38,1 \\
\hline
\end{tabular}

" Примечание. Здесь и далее - расчеты автора на основе микроданных обследования бюджетов домашних хозяйств по итогам 2018 г. [13]

Удельный вес наименее депривированных групп 5 и 6 составляет 10,7 \%, то есть почти совпадает с удельным весом самых богатых - с численностью верхнего дециля в упорядоченном распределении по величине среднедушевых располагаемых ресурсов в статистическом наблюдении Росстата. Согласно его данным, денежный доход самых богатых, составляющих верхний дециль, равен 71,3 тыс. р. на чел. в месяц [14], то есть почти в 2 раза больше, чем доход $10 \%$ наименее депривированных индивидов.

Удельный вес бедных по депривации соответствует численности первого и примерно половине второго дециля. Денежный доход индивидов, составляющих эти два нижних по уровню благосостояния дециля, равен 6-9 тыс. р. в месяц [15] - в 1,5-2 раза меньше, чем доход бедных по депривации.

Таким образом, доходная дифференциация индивидов, сгруппированных по степени депривированности, гораздо ниже, чем индивидов, сгруппированных по монетарному показателю по величине располагаемых ресурсов. Это означает, что субъективное восприятие индивидами своих финнансовых возможностей определяется не столько их доходами, сколько другими - немонетарными - факторами, и именно на этом должна строиться интерпретация депривационной бедности. Концептуальные принципы, на основе которых образованы группы депривационной и 
монетарной бедности, и соответствующие им показатели - самостоятельное позиционирование в иерархии финансовых возможностей и доходы как характеристика финансовых возможностей приводят к разному составу групп.

В целом обе группы - бедные по лишениям и бедные по доходам (рассчитанные по официальной абсолютной методике) - пересекаются по своему составу лишь на 1/3-1/4 (рис. 1). При этом среднедушевые денежные доходы домохозяйств, являющихся бедными по доходам, в 2018 г. составили около 8 тыс. р. в месяц [16, с. 36, 46], бедными по лишениям - 14,6 тыс. р. в месяц [17].

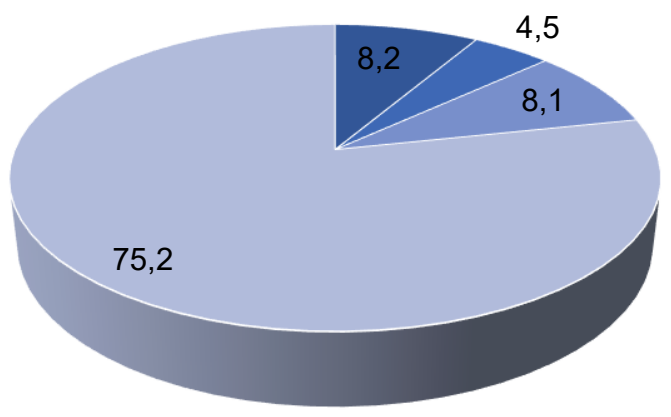

- только депривационная бедность
- только абсолютная бедность

- депривационная и абсолютная бедность

- небедные

\section{Рисунок 1 - Уровни различных типов бедности (по отношению ко всему населению РФ), \%}

Итак, доход, будучи основным дифференцирующим показателем в монетарных концепциях бедности, в депривационной концепции играет второстепенную, косвенную роль. Основным для нее оказывается показатель субъективного восприятия индивидами своих фринансовых возможностей в сфере потребления, которое связано с доходами достаточно сложно и неоднозначно.

Социально-демографическими фракторами, способствующими абсолютной бедности, являются местожительство в сельской местности, наличие детей в составе домохозяйства, многодетность, статусы неполной семьи и молодой семьи. Группы населения, формируемые данными фракторами, имеют повышенный риск попадания в категорию бедных по доходам (малоимущих) [18]. Что касается депривационной бедности, то она в меньшей степени определяется перечисленными факторами. Так, по выборке бюджетного обследования домохозяйств 2018 г., 23,1 \% индивидов, составляющих молодые семьи, и 36,2 \% индивидов, составляющих многодетные семьи, относятся к малоимущим (по методике абсолютной бедности), и только 18,8 и 28,3 \% - к депривированным. По неполным семьям и семьям, в составе которых есть инвалиды, риск депривированности несколько выше, чем риск абсолютной бедности: доли депривированных и малообеспеченных в этих группах - соответственно 32,4 и 29,3 \%, 18,7 и 15,5 \%. Уровни абсолютной и депривационной бедности сельского населения близки, составляя 21,7 и 19,4 \% [19].

Наибольшие различия, определяющие факторы депривированности, связаны с индивидами, составляющими семьи инвалидов и неработающих пенсионеров. Их доли среди малоимущих составляют 11,0 и 6,3 \%, а среди депривированных - 29,5 и 25,8 \% [20].

Важно также отметить, что размер домохозяйства и количество детей в нем, являясь заметными факторами абсолютной бедности (рост которой связан с ростом обоих показателей), оказывают на депривационную бедность гораздо более слабое (по количеству детей) или неоднозначное (по размеру домохозяйства) влияние (табл. 2).

Таблица 2 - Удельный вес численности малоимущего и депривированного населения в домохозяйствах, сгруппированных по размеру и по числу детей, \% [21]

\begin{tabular}{|l|c|c|c|c|c|c|c|c|}
\hline \multirow{2}{*}{ Группа } & \multicolumn{6}{|c|}{ Размер домохозяйства, чел. } & \multicolumn{2}{c|}{ Число детей в домохозяйстве } \\
\cline { 2 - 10 } & 1 & 2 & 3 & 4 & 5 и более & 1 & 2 & 3 и более \\
\hline Малоимущие & 1,6 & 3,1 & 7,8 & 15,9 & 30,0 & 11,1 & 24,0 & 52,1 \\
\hline Депривированные & 22,7 & 14,3 & 14,0 & 13,7 & 19,7 & 15,8 & 18,3 & 29,0 \\
\hline
\end{tabular}

Наиболее депривированными, по ощущениям, оказываются одиночки, при том что их риск абсолютной бедности - один из самых низких. 
Аналогичную картину, указывающую на слабую выраженность традиционных фракторов абсолютной бедности в бедности депривационной, можно наблюдать, сравнивая город и село. С 2004 г. уровень депривационной бедности в сельской местности превышает ее уровень в городе на 5-31\%. В то же время по уровню абсолютной бедности разница в последние годы составляла 3,1-4,3 раза [22, с. 23]. То есть концентрация депривированного населения в сельской местности гораздо меньшая, чем малоимущего; риск попадания в категорию бедных по доходам у сельского населения заметно выше, чем риск попадания в категорию бедных по лишениям.

Итак, субъективное восприятие собственных фринансовых возможностей в сфере потребления определяется не только уровнем доходов, но прежде всего социально-психологическими факторами. Ощущения депривированности усиливаются в семьях, состоящих из одиночек, инвалидов, неработающих пенсионеров. Оба показателя бедности - абсолютной и депривационной различаются на концептуальном уровне и формируют две слабо пересекающиеся по составу группы индивидов.

\section{Ссылки:}

1. Гришина Е.Е. Депривационный подход к оценке бедности семей с детьми в России и странах Европы // Финансовый журнал. 2017. № 4. С. 47-55.

2. Прокофьева Л.М. Бедность и социальная исключенность глазами разных групп населения / Л.М. Прокофьева, И.И. Корчагина, Р.И. Попова, О.С. Белокрылова, Ю.В. Филоненко, Е.В. Фурса // Народонаселение. 2014. № 4. С. 61-82.

3. Townsend P. Poverty in the United Kingdom. Harmondsworth, 1979.

4. Корчагина И.И., Прокофьева Л.М., Тер-Акопов С.А. Европейский опыт измерения бедности и социальной исключенности: индекс AROPE // Народонаселение. 2019. № 3. С. 162-175.

5. Фролова Е.Б. О совершенствовании методологических положений по расчетам индексов немонетарной бедности по итогам выборочных наблюдений по социально-демографическим проблемам : доклад на заседании научно-методологического совета Федеральной службы госстатистики. 2017 [Электронный ресурc]. URL: https://www.gks.ru/free doc/new site/rosstat/NMS/doc-frol.pdf (дата обращения: 15.02.2020).

6. Тихонова Н.Е. Феномен бедности в современной России // Социологические исследования. 2014. № 1. С. 6-19.

7. Давыдова Н.М. Депривационный подход в оценках бедности // Социологические исследования. 2013. № 6. С. 88-96.

8. Гришина Е.Е. Депривационный подход к оценке бедности семей ...

9. Итоги федеральных статистических наблюдений по социально-демографическим проблемам [Электронный ресурс]. URL: http://www.gks.ru/free_doc/new_site/inspection/itog_inspect1.htm (дата обращения: 15.02.2020).

10. Там же.

11. Гришина Е.Е. Динамика депривационной бедности в России // Вектор экономики : электронный научный журнал. 2019. № 4 (34) ; Сергиенко А.М. Социальная исключенность как форма сельской бедности: оценка масштабов и глубины в Алтайском крае и Республике Алтай // Ученые записки Алтайского филиала РАНХиГС. Вып. 8. Барнаул, 2011. С. 32-53.

12. Доходы, расходы и потребление домашних хозяйств (по итогам выборочного обследования бюджетов домашних хозяйств) : стат. бюллетень / Федеральная служба гос. статистики. М., 2008-2019.

13. Микроданные обследования бюджетов домашних хозяйств [Электронный ресурс] / Росстат. URL: https://obdx.gks.ru/ (дата обращения: 15.02.2020)

14. Доходы, расходы и потребление домашних хозяйств ...

15. Там же.

16. Социально-экономические индикаторы бедности в 2013-2018 гг. : стат. бюллетень / Росстат. М., 2019.

17. Микроданные обследования бюджетов домашних хозяйств ...

18. Шабанов В.Л. Динамика социально-демографического профиля бедности в России (в контексте изменений методических подходов Росстата в 2013-2017 гг.) // Теория и практика общественного развития. 2019. № 4 (134). С. 39-43 ; Его же. Сравнительный анализ концепций абсолютной и относительной бедности применительно к сельскому и городскому населению России // Региональные агросистемы: экономика и социология. 2019. № 2. С. 91-97.

19. Микроданные обследования бюджетов домашних хозяйств ...

20. Там же.

21. Там же.

22. Социально-экономические индикаторы бедности в 2013-2018 гг. ...

Редактор: Хорева Людмила Николаевна Переводчик: Мельников Евгений Вячеславович 